\title{
Production and Growth of Soybean on Water Hyacinth Bokashi Giving with Two Activators Types
}

\author{
Asrijal*1, Ambo Upe ${ }^{2}$, Rahmawati ${ }^{3}$, Sulfiani ${ }^{4}$, Dan Aslidayanti ${ }^{5}$ \\ ${ }^{1}$ Agricultural Science, STIP Puangrimaggalatung, Sengkang, South Sulawesi, Indonesia. \\ *corresponding author : email : rijalku238@g mail.com \\ ${ }^{2}$ Agricultural Science, STIP Puangrimaggalatung, Sengkang, South Sulawesi, Indonesia. \\ Email: amboupestip1969@gmail.com \\ ${ }^{3}$ Agricultural Science, STIP Puangrimaggalatung, Sengkang, South Sulawesi, Indonesia. \\ Email: wati rahma unhas@yahoo.co.id \\ ${ }^{4}$ Agricultural Science, STIP Puangrimaggalatung, Sengkang, South Sulawesi, Indonesia. \\ Email: sulfianiridwan@ymail.com \\ ${ }^{5}$ Agricultural Science, STIP Puangrimaggalatung, Sengkang, South Sulawesi, Indonesia. \\ Email: aslidayanti@gmail.com
}

\begin{abstract}
The study aimed to determine the production and growth of soybean on water hyacinth bokashi giving with two activators types. The study was conducted in Leweng Village, TakkalallaSubdistrict, Wajo District. The method used was Randomized Block Design (RBD), consisting of three (3) treatments, namely Bokashi (bo), Bokashi 2 tha ${ }^{-1}$ with Activator EM4 $\left(b_{1}\right)$, and Bokashi 2 tha ${ }^{-1}$ with Activator Tadabur $\left(b_{2}\right)$. Each treatment was repeated three times so that the number of treatment combinations was 9 combinations (9 plot treatment). The results show that the average soybean production per hectare application of water hyacinth bokashi with EM4 activators is 0.80 tons per hectare, while the application of water hyacinth bokashi with Tadabur activists is 0.79 tons per hectare. The application of water hyacinth bokashi with $\mathrm{EM}_{4}$ activators is much better, compared to water hyacinth bokashi with activist Tadabur.
\end{abstract}

Keywords-Bokashi, Water Hyacinth, EM $M_{4}$, Soybean, Tadabur.

\section{INTRODUCTION}

The use of organic materials is currently very important considering the level of organic matter in low agricultural soils. Land has a very important meaning for the life of mankind and the nature of the soil is very dependent on its constituent components. Soil organic matter is one of the most important components, which is the result of the decay of plant / plant remnants mixed with soil minerals in the topsoil (Suhardjo et al., 1998).

Soybeans are short-day plants, which will not flower if the length of irradiation (day length) exceeds the critical limit. The duration of irradiation is a function of latitude. Light intensity above 1,076 lux (100 foot candles) for 8 hours has been able to stimulate flowering, but flowering does not occur if the light intensity is less than 1,076 lux (Asrijal, 2004).

Water hyacinth has the potential to be made as compost (bokashi) because it turns out that this water plant has some organic fertilizer content. According to Fryer and Matsunaka (1988), water hyacinth is a material that is very potential to be used as organic fertilizer because based on the results of analysis in the laboratory it contains, among others: $1.681 \% \mathrm{~N}, 0.275 \% \mathrm{P}, 14.286 \% \mathrm{~K}, 37.654 \% \mathrm{C}$, with a ratio $\mathrm{C} / \mathrm{N} 22,399$.

According to Murbandono (2003), compost is organic materials (organic waste) that have undergone a weathering process because of the interaction between microorganisms (decomposing bacteria) that work in it. Organic materials such as leaves, grass, straw, the remnants of twigs, and branches, animal feces, fall flowers, urine. This composting process takes a long time, so Yovita (2003) suggests one activator that can accelerate the composting process by using effective microorganisms 4 (EM4) compost produced through the fermentation process with the provision of EM4 called Bokashi. The word bokashi is taken from Japanese 
which means fermented organic matter. By the Indonesian people the word bokashi is extended to "a rich source of organic matter".

EM4 activators are agricultural cultivation technologies to improve soil and plant health and fertility. EM4 contains lactobacillus, photosynthetic bacteria, yeast, actinomicetes, and decomposers which can be used as inoculants to increase the diversity of soil microbes to ferment organic materials into simple organic compounds that are easily absorbed by plant roots, so that the quality and quantity of crop production increases (Wididana and Teruo , 1996).

TadaburBiofertilizer Activator is one of the biological fertilizer products that are produced and marketed by PT. Quantum Innovation. Tadabur is a multi-use liquid organic biofertilizer which is highly concentrated by plants to stimulate growth and strengthen plants. Tadabur biological fertilizers enriched with organic phytohormones, complex aminino acids and enzymes (Anonim, 2013).

The use of bokashi is one way to improve the fertility of physical, chemical, and biological soil. However, the type and dose of bokashi needed by plants varies greatly, depending on the variety, availability of materials, and soil conditions. The advantage of using bokashi is high efficiency, does not interfere with nutrient balance in the soil, improves the physical, chemical, and biological properties of the soil so as to increase land productivity.
Therefore the use of organic fertilizers needs to be applied as a result of expensive inorganic fertilizer prices and to create more sustainable agricultural land (Farid, 2003).

\section{MATERIALS AND METHODS}

The study was conducted in Leweng Village, TakkalallaSubdistrict, Wajo District. The method used was Randomized Block Design (RBD), consisting of three (3) treatments, namely Bokashi ( $\left.\mathrm{b}_{0}\right)$, Bokashi $2 \mathrm{t} \mathrm{ha}^{-1}$ with $\mathrm{EM}_{4}$ (b 1 ), and Bokashi $2 \mathrm{t} \mathrm{ha}^{-1}$ activator with Tadabur Activator (b2 ) Each treatment was repeated three times so that the number of treatment combinations was 9 combinations ( 9 plot treatment).

\section{RESULTS AND DISCUSSION}

3.1. Research result

3.1.1. Plant height

The average plant height at the age of 60 days after planting and its variance is presented. Sidik Variety shows that plant height 60 days after planting on soybean plants on water hyacinth bokashi with two types of activators, showed a very significant effect on plant height 60 days after planting. The test results can be seen in Table $\mathbf{1}$.

Table 1. Average plant height 60 days after planting on soybean plants (strands).

\begin{tabular}{|l|l|l|l|}
\hline Treatment & Average & Different Test Results* & LSD ( level of 5\%) \\
\hline $\mathrm{b}_{0}$ & 47,20 & $\mathrm{~b}$ & 7,59 \\
\hline $\mathrm{b}_{1}$ & 65,31 & $\mathrm{a}$ & \\
\hline $\mathrm{b}_{2}$ & 64,09 & $\mathrm{ab}$ & \\
\hline
\end{tabular}

*) Different letters indicate differences at the level of $5 \%$

The LSD Test Results (level of 5\%) in Table 1, showed that the treatment of $b_{0}$ was significantly different from treatment $b_{1}$ and was not significantly different from the treatment of $b_{2}$, but between treatments $b_{1}$ and $b_{2}$ showed no significant difference in plant height 60 days after planting on soybean plants.

\subsubsection{Number of Pods}

The average number of pods of soybean at harvest and variance is presented. Sidik Variety shows that the number of soybean pods at the time of harvesting on the supply of water hyacinth bokashi with two types of activators, showed no significant effect on the number of soybean pods at harvest, which can be seen in Fig. 1 below. 


\section{Bokashi of Water Hyacinth}
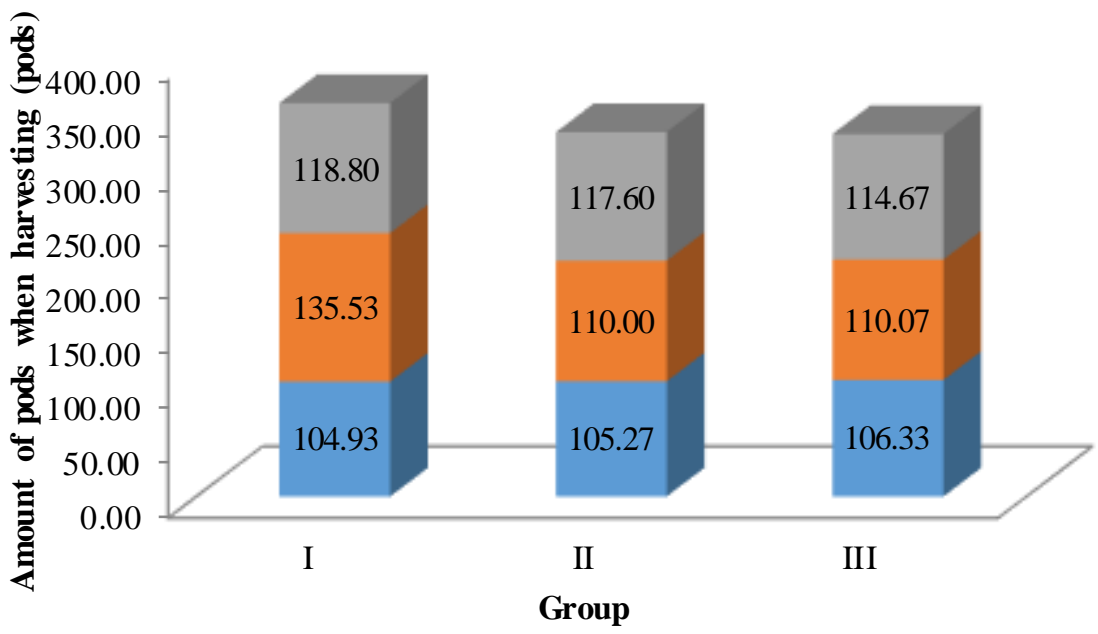

$\square \mathrm{b} 2$

- b1

b0

\section{Fig. 1. Amount of Soybean Pods during Harvest (pods)}

\subsubsection{Production per hectare}

The average production per hectare of soybean crops at harvest and variance is presented. Sidik Variety shows that the production per hectare of soybean at harvest time for the administration of water hyacinth bokashi with two types of activators, shows an unrealistic influence on the production per hectare of soybean plants at harvest, which can be seen in Fig. 2 below.

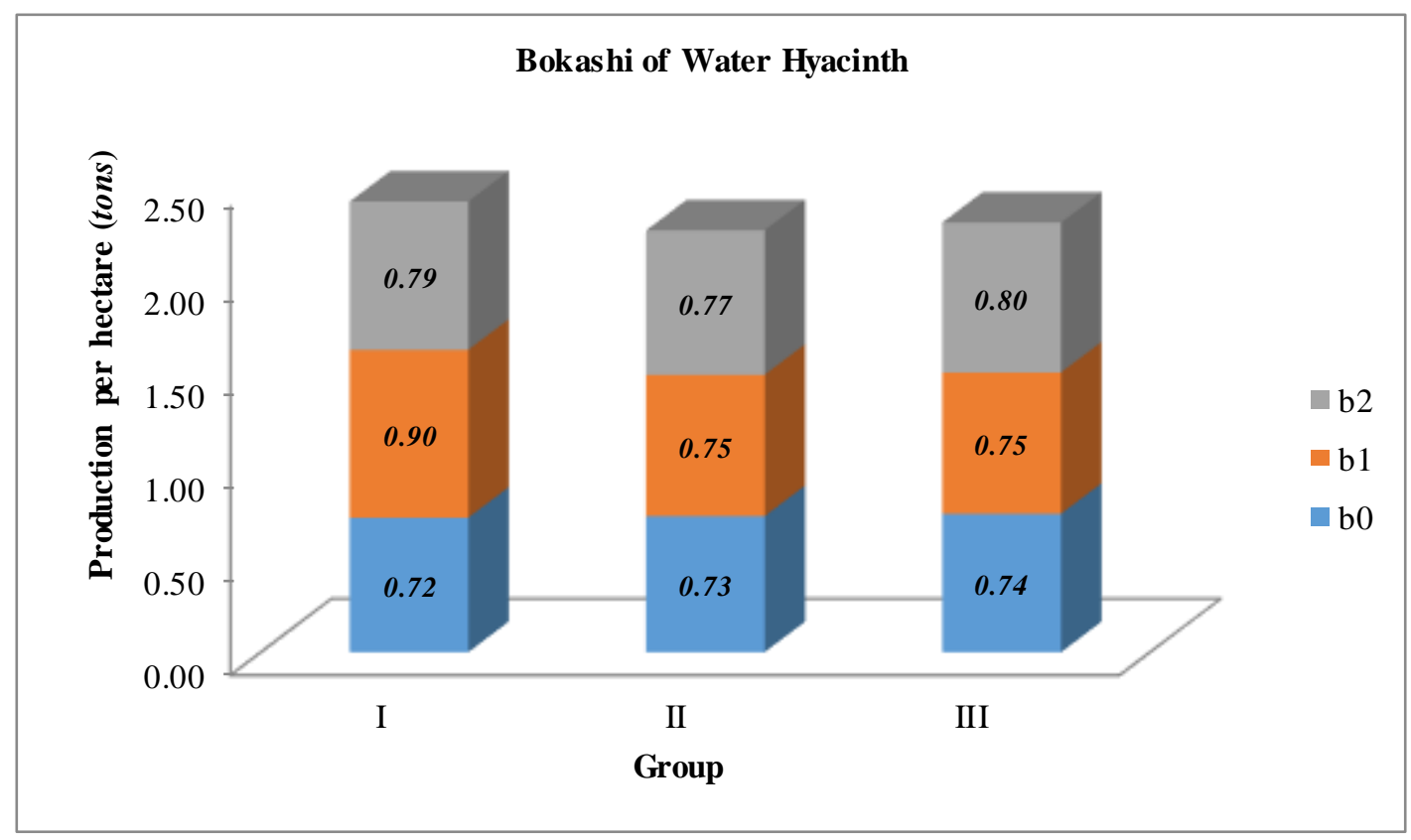

Fig. 2. Production per hectare of soybean plants during harvest (tons)

\subsection{Discussion}

The growth and development of a plant must be supported by the availability of nutrients. Especially macro nutrients, besides also other micro elements, to support the process of forming plant tissues. According to Situru (1998), that macro nutrients are needed by plants for growth until production in large quantities, especially in the process of fruit formation.

The relationship in the process of forming plant tissue, macro nutrients must support each other, so that the 
formation of a strong network causes smooth process of absorption and utilization of nutrients for plants. In the opinion of Wolverton, (1978), that if one or several nutrients are not in sufficient quantities or one of them in excessive amounts, the plant will show symptoms such as lack of nutrients.

The results showed that administration of water hyacinth bokashi with EM4 activists and Tadabur activators showed a significant effect on parameters (plant height, number of leaves, and number of branches), but showed no significant effect on parameters (number of pods; number of empty pods; dry weight ; and production of samples / plot / per hectare). This is because the accumulation of nutrients available has not been able to support growth to production maximally, meaning that the nutrients available in this case are water hyacinth bokashi with both EM4 activists and Tadabur activators, not yet available in balanced conditions so that photosynthesis and metabolic processes support the development of plant organs shows results that are not optimal. Likewise, if viewed from the results of analysis through Fig 2, the average production per hectare is good without bokashi treatment $\left(b_{0}\right)$, bokashi activator $\mathrm{EM}_{4}\left(\mathrm{~b}_{1}\right)$, and bokashi activator Tadabur $\left(b_{2}\right)$, respectively $0.73,0.79$, and $0.80 \mathrm{t} \mathrm{ha}^{-1}$. The total average turns out to show low production yields of $0.77 \mathrm{t} \mathrm{ha}^{-1}$. If compared with the average production in the Pacet experimental garden reaches $2.19 \mathrm{t} \mathrm{ha}^{-1}$, while in Citayam it is only $0.99 \mathrm{t} \mathrm{ha}$ ${ }^{1}$ (Asrijal, 2004).

\section{CONCLUSIONS}

Based on the results and previous discussion, it can be concluded that the application of water hyacinth bokashi with activator EM4 is much better, compared with water hyacinth bokashi with activist Tadabur. With an average production per hectare of 0.80 tons per hectare.

\section{ACKNOWLEDGEMENT}

The author is grateful to the General Chairperson of the Sengkang Puangrimaggalatung for financial support through the research funding Mandiri 2017.

\section{REFERENCES}

[1] Anonim, 2013, TadaburSahabat Flora (100\% Organik). PT. Inovasi Quantum

[2] Asrijal, 2004. Penggunaanbokashiecenggondok (Eichhorniacrassipes) padasistempertanamantunggaldantumpangs arikedelai, jagung, danpadigogo. Tesis. Pascasarjana Universitas Hasanuddin, Makassar
[3] Farid, M., 2003. Pertumbuhandan Produksi KapasTransgenik BtpadaBerbagai Jenisdan Dosis Bokashi. J. Agrivigor, 3(3):275-280

[4] Fryer., J.D., dan S. Matsunaka 1988., Penanggulangan Gulma Secara Terpadu., Bina Aksara, Jakarta.

[5] Murbandono, 2003.2 MembuatKompos. PenebarSwadaya, Jakarta.

[6] Situru, $1998 . \quad$ PemanfaatanEcengGondok (Fichhorniacrassipes) untuk Pakan Melalui Sistem Daur Ulangoleh Cacing Tanah (Pheretimaasiatica). Disertasi, Program Pascasarjana Universitas Has anuddin, Makassar.

[7] Suhardjo, Soepartini, danKurnia, U. 1998.,Bahan Organik Tanah InformasiPenelitian Tanah, Air, PupukdanLahan. PengembanganPenelitian, PusatPenelitian Tanah danAgroklimat, Bogor.

[8] Wididanadan Teruo, 1996. Teknologi Effective Microorganisms 4 (EM Teknology). Songgolangit Persadadan Indonesia Kyusei Nature Farming Societes (INKFS), Jakarta.

[9] Wolverton, 1978. Nutrient Composition Water Hyacinths Grown on Domestic Sewage. Econ. Bot. 32 (4)

[10] Yovita H.I., 2003. Membuat Kompos Secara Kilat. Penebar Swadaya, Jakarta. 